\title{
O TECLADO ACENDE O ÉCRAN: A POESIA CINEMATOGRÁFICA DE MANUEL GUSMÃO
}

\author{
Marleide Anchieta de Lima \\ (Universidade Federal Fluminense)
}

\section{RESUMO}

A poética de Manuel Gusmão investe de forma intensa nas relações interartes. Suas obras propõem diálogos visuais com a pintura, a fotografia e, sobretudo, experimentam a dinamicidade do cinema. Por este motivo, nosso trabalho pretende analisar a construção imagética em alguns poemas do autor mencionado, mas sem se restringir ao âmbito temático, uma vez que investigaremos a transposição de técnicas cinematográficas para a composição textual e os sentidos que tais procedimentos expressam na tentativa de dizer, ou talvez de não dizer, o objeto visualizado. Com essa perspectiva, recorreremos às abordagens teórico-críticas de George Didi-Huberman, Jacques Aumont e Gilles Deleuze, além da prosa de Herberto Helder, em Photomaton \& Vox.

PALAVRAS-CHAVE: poesia contemporânea portuguesa; relação interartes; Manuel Gusmão.

\begin{abstract}
The poetry of Manuel Gusmão invests intensively in interart relations. His works offervisual dialogue with painting, photography and, above all, experience the dynamics of the cinema. For this reason, our study aims to examine the construction imagery in poems of the author mentioned, but not limited to thematic scope, since it will investigate the implementation of cinematic techniques for composition and textual meanings that express such procedures in an attempt to say or maybe not to say, the object being viewed. With this pesrpective, we turn to the theoretical-critical of George Didi-Huberman, Jacques Aumont, Gilles Deleuze, and the prose of Herberto Helder in Photomaton \& Vox.
\end{abstract}

KEYWORDS: Contemporary Portuguese poetry; interart relations; Manuel Gusmão. 
que passam por entre as folhas de um livro como num jardim.

Então o teclado acende o écran e as nuvens passam na literatura e passam por aqui, segundo o elogio e a promessa."

(GUSMÃO, 1996, p. 34)

As sociedades contemporâneas vivem momentos de uma plural e excessiva visualidade. Seja através dos letreiros luminosos dos outdoors, seja dos anúncios televisivos ou dos reality shows, o que se produz é para ser, antes de tudo, consumido pelo olhar. Essa demasia visual torna quase tudo indistinguível, impossibilitando-nos de ver o que não é facilmente visto, já que pode interferir em nossa experiência sensível e em nossa capacidade de conhecimento e percepção de mundo. Por esse motivo, cada vez mais se faz necessário compreender o que é a imagem e, consequentemente, construir um percurso crítico que desestabilize os aspectos banalizantes da lógica capitalista.

Vale ressaltar que o conceito de imagem é amplo e, de certo modo, empregado em contextos diferenciados, o que o torna ainda mais complexo. Não à toa, há séculos, filósofos, poetas, entre tantos pensadores, buscam atribuir-lhe um sentido. Imagem - palavra oriunda do latim imago e correspondente a eidos, ideia em grego $^{1}$ - foi definida como sombras, reflexos ou representações próximas da realidade, ou ainda, como algo que está no lugar de outro objeto com o qual mantém relação de semelhança. Ela foi também entendida como aquela que é "formada por raios luminosos após a passagem por um sistema óptico" e, além disso, significa “a impressão sensorial que persiste mesmo quando o estímulo que a causou não está mais atuante" (HOUAISS, 2008, p. 654). De uma forma ou de outra, abarcando os sentidos de efeito mágico, de representação mimética, de experiência ótica ou de simulação técnica ${ }^{2}$, seus possíveis conceitos remetem a uma presença da ausência e a um jogo de alteridade que estão inerentes à sua constituição.

$\mathrm{Na}$ tentativa de ser o outro e de se corporificar através da palavra, da coloração e do movimento, a imagem descobre o vazio intrínseco ao que se dá a ver e àquilo que é difícil de enxergar e de dizer. Desse modo, não há como excluí-la do âmbito poético, pois também atua com os signos do poema, experimentando a relação lacunar entre as coisas e seus nomes, a materialidade da escrita e os sentidos múltiplos que expressa. Por essa razão, o poeta e crítico Octavio Paz assegura que "a palavra poética é [...] ritmo, cor, significação - e, ainda assim, é outra coisa: imagem. A poesia converte a pedra, a cor, a palavra e o som em imagens" (PAZ, 1982, p. 27). 
No processo de construção, o poeta articula a capacidade criativa do verbal e do visual para reinventar objetos e mundos. Ele convive com o silêncio do ainda não dito e o preenche com significados e imagens, tentando exprimir não só o que é possível se concretizar no papel, mas o indizível, o não visto pelos olhos acostumados à visualidade cotidiana. É dessa forma que a morte, o amor e o tempo, temas universais que atravessam os séculos, adquirem configuração imagética no poema. Por meio de metáforas, símiles, alegorias e outros recursos estilísticos, criamos imagens mentais daquilo que lemos. Com essa perspectiva, retomamos as ideias de Octavio Paz: "A imagem diz o indizível [...]. Há que retornar à linguagem para ver como a imagem pode dizer o que, por natureza, a linguagem parece incapaz de dizer." (PAZ, 1996, p. 44).

De um modo próximo à imagem poética, as imagens projetadas num écran demonstram a constante ambivalência entre presentificação e ausência, o que é perceptível através do jogo de luzes e sombras, de concretude e abstração, de real e imaginário. Por este motivo, Einsestein e Godard, nomes fundamentais na história do cinema, exploraram os âmbitos intersticiais decorrente do processo de montagem, assim como a potencial "emergência de uma imagem ausente" (MARTELO, 2008, p. 193). Nesse sentido, eles ativavam seus arquivos mentais, imateriais e invisíveis, transformando-os em algo presentificado através da construção fílmica.

No cinema, a imagem é considerada um indispensável elemento de linguagem, ou seja, ela é o item fulcral para compor um filme e desencadear uma significação. Daí surge seu trabalho com as imagens em movimento, dispostas em vinte e quatro fotogramas por segundo e capazes de desestabilizar nossas noções de tempo e de espaço. O cineasta com seus procedimentos e sua equipe, tal como o poeta e seus instrumentos de escrita, exprime com os recursos imagéticos aquilo que a poesia expressa com as palavras. No entanto, a imagem é uma forma de interlocução entre essas duas manifestações artísticas. Rosa Maria Martelo, no artigo "Quando a poesia vai ao cinema”, cita o ensaio de Tynianov em Poetica Kino, [...]”, a fim de explicitar os pontos de encontro dessas artes aparentemente díspares:

"[...] Os quadros alternam da mesma maneira que um verso sucede a outro, ou uma unidade métrica a outra, sobre uma fronteira precisa. O cinema desenvolve-se por saltos de um a outro quadro, tal como a poesia de um verso a outro verso. Por estranho que possa parecer, se quisermos estabelecer uma analogia entre o cinema e as artes do verbo, a única relação legítima será não entre cinema e a prosa, mas entre o cinema e a poesia." (ARTAUD apud MARTELO, 2008, p. 180)

A alternância na montagem de planos ou de versos resulta naquilo que é fascínio para as artes em questão, ou seja, a projeção de imagens. Tal processo compositivo mostra-nos que poesia e cinema investem no imaginário e na dinamicidade da visão. Esse papel ativo do olhar as- 
sociado à imagética que mentalmente criamos provoca em muitos poetas contemporâneos, entre eles os que se inserem na Literatura Portuguesa, uma necessidade estética de incorporar os suportes artísticos da linguagem cinematográfica aos recursos estilísticos da poesia. Talvez esta seja uma das razões que levou Ruy Belo, poeta português, a afirmar que "o cinema [o] ensinou a ver" (BELO, 2000, p. 188).

Assim, Ruy Belo enuncia dois aspectos dessa aprendizagem: o enquadramento do olhar obtido por representação de planos ou sequências fílmicas; e a maneira como a escrita se vale de uma visão cinematográfica na elaboração do poema. Quanto a isso, o poeta Herberto Helder, também pertencente ao contexto português, corrobora o pensamento beliano, sinalizando a cumplicidade entre poesia e cinema:

A escrita não substitui o cinema nem o imita, mas a técnica do cinema, enquanto ofício propiciatório, suscita modos esferográficos de fazer e celebrar. Olhos contempladores e pensadores, mão em mãos seriais, movimento, montagem da sensibilidade, música vista (ouçam também com os olhos!), oh, caminhamos para a levitação na luz! (HELDER, 1998, p. 7)

"Modos esferográficos" de transpor o fílmico para o registro poético, "de fazer e celebrar" a linguagem são, de forma similar, cultivados por Manuel Gusmão, poeta e crítico renomado em Portugal, cujo trabalho literário é nosso objeto de análise neste ensaio. Sua obra apresenta-se como um ato dinâmico, em que as intersubjetividades circulam, as palavras são cíclicas e as paisagens deslocam-se continuamente: "A teia que as mãos inventam sobre as teclas é uma página/ páginas que se vão voltando como um sistema de portas/ de corredores que abrem sobre corredores na água" (GUSMÃO, 1996, p. 34).

O poeta, através de produtivo diálogo entre poesia e cinema, desenvolve novas formas de olhar e pensar o mundo. Aliás, os efeitos de processos fílmicos em seu projeto poético ativam outras possibilidades de configuração da imagem, levando em conta as "aproximações, fusões e extensões, descontinuidades, contiguidades e velocidades" (HELDER, 1998, p. 8) no trânsito de filmes para poemas.

A cinética literária de Gusmão envolve o co-mover a poesia, sua "razão apaixonada"3 (GUSMÃO, 1994, p. 234). Para isso, além de sensibilizar, perturbar e desestabilizar por meio da palavra, ele instiga uma discussão profícua acerca das artes e da história, convocando uma multiplicidade de vozes que lhe permitem reelaborar a tradição. Então, o poeta enfatiza a articulação da "escrita trabalhadamente cerebral" com a "construção da intensidade sentimental" (MAGALHÃES, 1999, p. 215), conforme é sublinhado neste poema de Dois sóis, a rosa/ a arquitectura do mundo:

a rosa trabalha como a i-

maginação rigorosa. O mundo inventa essa pedra imaginante que se põe a abrir no cérebro as suas pétalas. 
Afectada pela paixão, imagina uma alegria que acompanha a ideia de uma causa exterior que acrescenta o poder de agir do corpo. (GUSMÃO, 1990, p. 101).

Como podemos notar, o texto ressalta as imagens mentais e teoriza a formação das mesmas num âmbito metapoético. Há um jogo contínuo entre o sensível e o inteligível. O poema, como "rosa", "trabalha", "inventa" e "imagina”. Isso significa que ele é capaz de mover e aproximar elementos díspares: a imaginação com o rigor - "pedra imaginante -, o cerebral com a paixão, a alegria a acompanhar a ideia. São "caligrafias extremas" (HELDER, 2006, p. 10) a mobilizar racionalmente a sensibilidade e a se tornar suscetível a ela.

A poética de Manuel Gusmão provoca uma tensão no corpo verbo-visual que se projeta na folha em branco. Ela solicita a ação de uma corporeidade que se espacializa no texto e se entrelaça à "carne do mundo" (MERLEAU-PONTY, 1964, p. 197). Nessa dinâmica, sua grafia transforma-se num corpo migrante a percorrer as páginas, as vozes e a visualidade que se dá a perceber na poesia: "tocas com os dedos uma letra que se repete e difere e/ abre no mundo uma passagem por onde o mundo passa" (GUSMÃO, 1996, p. 33). Vale lembrar que, além da percepção, no cinepoiesis de Gusmão, "entram em jogo o saber, os afetos, as crenças e as questões históricas" (AUMONT, 1993, p. 59). Tudo se passa no écran que o poeta está a inventar com suas "mãos imaginantes", com a experiência de uma linguagem criadora a unir cinema e poesia.

\section{CINEPOIESIS: O CLINAMEN DE MANUEL GUSMÃO}

Se alguns poemas já haviam ensinado a "sensibilidade do olhar" (HELDER, 1998, p.8), experimentar a visualidade cinematográfica e os recursos propiciados pela câmera de filmar ofereceu aos poetas outra concepção do visível, assim como um diverso tratamento imagético para a poesia. Desse modo, o poema assemelha-se à tessitura fílmica, em que o lápis-câmera assimila os efeitos ópticos, os planos, os raccords e as montagens, ou seja, estabelece uma relação interdiscursiva com as técnicas de captação e de movimento das imagens. O trânsito entre o verbal e visual torna-se cada vez mais propício à "transcodificação intersemiótica" entre o cinematográfico e o poético (SILVA, 1990, p. 179).

Manuel Gusmão já percebeu que o diálogo enriquecedor entre essas artes proporciona um jogo ainda mais inventivo com palavras e imagens. Ele analisa as homologias estruturais de cada código artístico para construir possibilidades de sentido e efeitos na montagem sígnica dos poemas. As estratégias de visualidade empregadas por Gusmão parecem coadunar com a asserção do crítico paulista Aguinaldo Gonçalves ao mencionar que "uma arte pode aprender com outra o modo com que se serve de seus meios para depois, por sua vez, utilizar os seus da mesma forma; isto é, segundo o princípio que lhe seja próprio exclusivamente" (GONÇALVES, 1994, p. 208). 
Com efeito, o poeta com "as máquinas de filmar nas mãos" (HELDER, 2006, p.140) lança-se a uma reflexão metapoética e sugere um olhar atento para a experiência temporal e para a exploração das imagens tão caras ao cinema: "[...] página a página abre-se um écran/ e os ruídos desenham sob os versos o fragor do mar./ Então, o filme varre o teu cérebro, lança o claro fogo/ à copa das suas árvores, e tu estremeces, coisa convulsa" (GUSMÃO, 2004, p. 10).

Entre os elementos cinematográficos, Gusmão valoriza a iluminação como matéria-prima fílmica indispensável para a materialização imagética. Tal recurso é de grande relevância na elaboração de um filme, na medida em que configura as mensagens subjetivas e cenográficas do cinema. Ela ressalta a cor, a sensibilidade, a profundidade e os aspectos mais fantásticos que possamos imaginar. Ela vibra, acende, apaga, enfatiza, esfuma e emprega o poder transfigurador da câmera. De acordo com Federico Fellini:

No cinema, a luz é ideologia, sentimento, cor, tom, profundidade, atmosfera, história. Ela faz milagres, acrescenta, apaga, reduz, enriquece, anuvia, sublinha, alude, torna acreditável e aceitável o fantástico, o sonho, e ao contrário, pode sugerir transparências, vibrações, provocar uma miragem numa realidade mais cinzenta, cotidiana. Com um refletor e dois celofanes, um rosto opaco, inexpressivo, torna-se inteligente, misterioso, fascinante. A cenografia mais elementar e grosseira pode, com a luz, revelar perspectivas inesperadas e fazer viver a história num clima hesitante, inquietante; ou então, deslocando-se um refletor de cinco mil e acendendo outro em contraluz, toda a sensação de angústia desaparece e tudo se torna sereno e aconchegante. Com a luz se escreve o filme, se exprime o estilo. (FELLINI, 2000, p. 182)

O investimento na luminosidade aparece de forma recorrente na poesia de Manuel Gusmão. Com ela, o poeta assinala a ideia de transformação e deslocamentos das "sílabas da luz". Sua "caligrafia luminosa" incorpora o processo cosmogônico de morte e nascimento da matéria através da força inventiva do poieín artístico: "O homem com o seu labirinto portátil chegou/ e carrega no interruptor do poema: - a sala e a mesa amadas/ a biblioteca de fogo, a gravura submersa [...]/ [...] Todas as coisas estremecem na luz da lâmpada" (GUSMÃO, 2004, p. 30).

Não à toa, ele visita tempos pretéritos e remete-se a Lucrécio, poeta e filósofo latino, ao pensar na cosmogonia de Epicuro na obra De Rerum Natura - "os átomos como as letras continuam/ a declinar os corpos e os nomes de cada coisa" (GUSMÃO, 2001, p. 21). Desse modo, Gusmão faz referência ao clinamen $^{4}$, ou seja, uma constante chuva de átomos lumi- 
nosos que, ao cair, se chocam, garantindo que "o mundo se renove e que novos corpos estejam sempre a nascer, a chegar às margens da luz" (GUSMÃO, 2008, p. 14). Como se pode notar, o fenômeno atômico é comparado à reunião de letras para formar uma corporeidade verbo-visual regida por uma movimentação contínua no espaço-tempo da escrita.

Além disso, Manuel Gusmão associa a teoria de desvio do clina$m e n^{5}$ à arte cinematográfica, uma vez que esta, formada por estilhaços de luzes, se organiza em fotogramas cujo efeito ilusório é resultado de fragmentações e recomposições. Gilles Deleuze, em Cinema I - Imagem-movimento, também seguindo a visão de Lucrécio, comenta que "o universo é como um cinema em si, um metacinema" (DELEUZE, 1983, p. 88). A sétima arte assemelha-se, sob esse ponto de vista, ao universo e seus astros em movimento, pois, tanto no mundo visível quanto na tela, a luz é um elemento fundador e os corpos imagéticos funcionam como projeções de sombras em deslocamento constante: “Aos senhores' escutem a química das palavras, como elas reagem à passagem do poema, iluminando-se e rodando como se fosse um sistema sideral" (GUSMÃO, 2007, p. 72). Assim, a escrita torna-se algo ígneo, em que "milhões de grãos luminosos, de gotas, de sílabas de luz” (GUSMÃO, 1990, p. 32) ativam-se na página, assim como as imagens projetam-se na sala escura.

A concepção lucreciana é também empregada por Manuel Gusmão como um recurso cinematográfico, ou seja, ele se vale do plano plongée - um tipo de enquadramento em que a câmera focaliza as imagens numa visão completamente voltada para baixo (MARNER, 2006, p. 135), de forma similar à declinação dos átomos em De Rerum Natura. Nesse sentido, ele reitera a proposta de Herberto Helder de que a poesia faz o uso da verticalidade, "a visão vertical - abissal - dos seus próprios panoramas, móveis (assim) em todos os sentidos e direções, e até imóveis" (HELDER, 2006, p. 58). É essa a visão do "poema que nos ensina a cair", de Luíza Neto Jorge, que, aliás, se coaduna com a ideia de queda presente em boa parte da tradição lírica portuguesa ${ }^{6}$. No poema "Um dilúvio que subisse", de Migrações do fogo, Gusmão demonstra o eixo inclinado de seu olhar-câmera:

Há muito que este homem aprendera a perder coisas pelo caminho. Sabia agora que perder era uma incisão na pele, e então uma coisa por aí caía com o som veloz de um crepitar eléctrico: um pássaro voando raso sobre o fio de um rio. $[\ldots]$

Essas coisas caem como coisas caindo, porque é da natureza das coisas o caírem na estação antepenúltima e ardente, naquela sazão que ardendo se enfria.

Ou como um braço que ao longo do tronco caísse: 
caíram braço - antebraço - e mão: assim.

Assim abandonando no fim a mão que esquece.

Caem com a tarde unhas e dedos, os dentes frios

Descem a sua queda até aos pulmões que explodem.

[...] (GUSMÃO, 2004, p. 27-28)

O poema acentua a situação de queda, através da recorrência do verbo cair conjugado em tempos diferenciados - "caía", "caem", "caindo", "caírem", "caísse", "caíram" - e das imagens que parecem vistas pelo ângulo verticalizado do plongée - "uma coisa por aí caía”, "um pássaro voando/ raso sobre o fio de um rio", "caíram o braço - antebraço - e mão", "descem a sua queda até aos pulmões", entre outras. O sujeito poético, marcado pelo signo da perda, aprende com a declinação a (des)ordem cíclica do mundo e de si mesmo: "Isso que é feito/ do que de nós cai e assim regressa ao lugar onde nascemos." (GUSMÃO, 2004, p. 28). De acordo com Didi-Huberman, em $O$ que vemos, o que nos olha, "a modalidade do visível torna-se inelutável [...], quando ver é sentir que algo inelutavelmente nos escapa, isto é: quando ver é perder." (DIDI-HUBERMAN, 1998, p. 34). É essa ideia de perda que exige do sujeito uma nova aprendizagem, ou melhor, a percepção da presença e da ausência que se encontram na "ordem do mundo contíguo" ao corpo (GUSMÃO, 2004, p. 27).

Além disso, o poeta exercita sua visão cinematográfica e inicia o poema valendo-se do plano de conjunto, no qual se registram as ações dos personagens no cenário (MARNER, 2006, p. 74) - "Há muito que este homem aprendera/ a perder coisas pelo caminho. [...]/ e então uma coisa por aí caía com o som veloz" (GUSMÃO, 2004, p. 27). Paulatinamente, o autor introduz planos de detalhe (planos de aproximação), conduzindo o leitor aos fragmentos do corpo e à percepção da mutabilidade do mesmo no decorrer do tempo. Desse modo, há um zoom do olhar-câmera para ressaltar a declinação corpórea: “Ou como um braço que ao longo do tronco caísse:/ caíram braço - antebraço - e mão: assim./ Assim abandonando no fim a mão que esquece.” (GUSMÃO, 2004, p. 28).

No poema citado, não só o cinema é evocado, mas também ecos de versos da tradição, como por exemplo, os de Sá de Miranda: "O sol é grande, caem cóa calma as aves/ do tempo em tal sazão, que soe ser fria;" (MIRANDA, 1939, p. 29) -, ou ainda os de Luiza Neto Jorge, em "Fracturas": "Nos desertos - íntimos, insuspeitos -/ já caem com a calma as avestruzes/ - ou a distância, com os oásis, finda" (JORGE, 2008, p. 80). Sejam as "aves", sejam as "avestruzes" ou "unhas e dedos, os dentes frios", o movimento de queda cruza fios espaço-temporais, de modo que essas imagens percorram tempos diferentes, inscrevendo Sá de Mirando, Luiza Neto Jorge e tantos outros poetas no tempo constelado do cinepoiesis de Manuel Gusmão. 


\section{UMA ESPÉCIE DE CINEMA NA CABEÇA}

Nas palavras de Manuel Gusmão, somos um cinema ambulante, pois “todos nós temos uma espécie de cinema na cabeça que consiste numa máquina que projecta num ecrã onde vemos a imagem, numa sala escura com pessoas lá dentro" (GUSMÃO, 2007, p. 117). Em sua poesia, o autor faz inúmeras referências a figuras que se formam no espaço cerebral e se materializam através da noite associada à câmara escura, tais como "no coração da rosa a noite/ abre as alas/ do brilho" (GUSMÃO, 1990, p. 163); "[a noite do clinamen]/ e devolve-a inteira/ à sombra que as mãos escrevem no ar” (GUSMÃO, 1996, p. 93); “[...] o cinema/ da noite em fogo em que tu apareces viva/ e toda feita de sonho" (GUSMÃO, 2001, p. 26); "o fascínio que quase rima/ com o abismo de uma pequena caixa cheia de uma noite azulada." (GUSMÃO, 2004, p. 65).

De acordo com o poeta, nosso cérebro ativa, através de processos psíquicos e perceptivos, uma produção imensurável de imagens mentais. Estas, por sua vez, tomam "por objeto relações, atos simbólicos, sentimentos intelectuais" (AUMONT, 2004, p. 162), o que, de certa forma, assinala a presença de uma subjetividade imagética. Constantemente, processamos uma gama de informações visuais e, de modo consciente e/ou inconsciente, construímos novas imagens. Tal como no cinema, procuramos meios de projetá-las. No tocante ao trabalho poético, essa projeção não ocorre diretamente, pois o poeta precisa da mediação da linguagem para elaborar, com a escrita-câmera, a visualidade do poema. Assim, o papel torna-se écran e as palavras, a possibilidade de concretização do imaginário. Acerca disso, escreve Gusmão: "[...] Na cabeça, lentamente, as frases voltam a acender-se, fazem um barulho de páginas que se viram; deslizam umas sobre as outras: [...] As ondas brilham escuras no cérebro nocturnamente

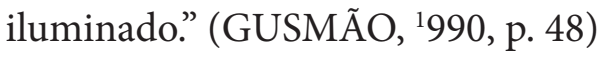

Manuel Gusmão considera o poema um trabalho permanente da imaginação, no qual se ativam associações de imagem na consciência do sujeito e os nexos imagéticos que fluem como numa sala escura de um cinema-sonho: "A tua cabeça acende uma noite/ e o seu luar./ Então os horizontes confundem-se/ e alucinação vem" (GUSMÃO, 1996, p. 76). Desse modo, o poeta emprega a potencialidade de seu olhar cinematográfico na articulação poemática, transformando a escrita em imagem de movimento e de revitalização através da dinâmica alucinada presente no corpo deslocado e vertiginoso das palavras.

Rosa Maria Martelo, no artigo "Poesia, imagem e cinema: 'Qualquer poema é um filme?", retoma as ideias de Godard e observa que o cinema possui "essencialmente uma memória de imagens, não uma memória de histórias" (MARTELO, 2007, p. 201). Essa "memória de imagens" fílmicas entrecruza-se com inúmeras outras na poética de Gusmão, e, ao mesmo tempo, propicia o exercício cinematográfico de escrever relações intersemióticas. Numa entrevista a Rosa Mesquita, o autor explica: 
Os filmes que "aparecem" na minha poesia vêm de diferentes distâncias no tempo, raramente dão origem imediata a poemas ou a motivos deles. É preciso que tenham provocado alguma e-moção ou co-moção, quando vistos ou revistos, e que depois tenham atravessado os tempos, até acontecer que venham a ser necessários a um clima, a uma narrativa ou tão só a uma imagem que, no poema, deve mover-se, incendiar-se ou quietamente fulgurar. Alguns dos planos que eu "cito" são por vezes construções feitas de imagens misturadas de diferentes filmes e, nesse sentido, inventadas pela poesia. (GUSMÃO apud MESQUITA, 2007, p. 158)

Como podemos perceber, para Gusmão, a miscelânea imagética de sua poesia considera elementos importantes como "distâncias no tempo", "e-moção ou co-moção" e relevância "a um clima, a uma narrativa ou tão só a uma imagem”. São essas as categorias eleitas para dar a ver o acervo mental do poeta. A trama espaço-temporal, que é o poema-filme proposto pelo autor, reitera a cinética verbo-visual mnemônica capaz de "se lembrar sem imitar" aquilo que foi projetado (DIDI-HUBERMAN, 1998, p. 114). Assim, se existe ecfrasis na escrita do referido poeta, ela ocorre na transposição das estratégicas fílmicas para a composição poemática, pois não há preocupação do poeta em guiar o leitor em torno das imagens visualizadas e muito menos de construir uma evidência descritiva, a fim de clarear aquilo que é posto diante dos olhos. Ao contrário, ele nos leva a relativizar tal conceito e a adequá-lo ao contexto estético contemporâneo.

Investir no diálogo com a arte cinematográfica é, para Gusmão, um meio de incorporar no lírico a dimensão narrativa, de modo que, numa sequência de planos, ele promova a teatralização de subjetividades e entrecruze registros biográficos, palavras alheias e fragmentos de filmes. Em Migrações do fogo, identificam-se técnicas do olhar próprias do cinema, sobretudo nos segmentos em que o autor cita a filmografia de Wong Kar-Wai, Kurosawa, Orson Welles, Dreyer, Teresa Vilaverde e outros. A crítica brasileira Maria Esther Maciel, no livro A memória das coisas: ensaios de literatura, cinema e outras artes plásticas, mostra-nos que, em determinadas circunstâncias, o poético vale-se de "recursos como a velocidade ou a lentidão, as proximidades íntimas dos primeiros planos, as variações da luminosidade, etc., busca trazer para a tela aquele algo que subjaz à realidade visível das coisas" (MACIEL, 2004, p. 73). São esses recursos que Gusmão resgata para sua escrita, como se pode notar neste excerto do poema "Como coisas caindo":

Por ruas sem céu onde apenas chegam cadentes alguns reflexos do laser, corredores em ruínas de uma metrópole falsa. Tudo se passa no filme que alguém está a inventar na tua cabeça que as labaredas alucinam: nem Daedalus nem Ariadne são, apenas dois que tendo-se encontrado se procuram, que se afastam e se aproximam; sempre a caminho 
do desencontro que é a sua destinação sem destino:

O amor sem memória que não a da promessa.

Há uma música - cordas que vibram a folhagem nervosa do céu enquanto a percussão vinda do fundo chega alta e devagar retira-se para que uma flauta se acenda ondulante e se interrompa breve - uma música sem voz que ao silêncio desse uma língua viva, uma música que os dança na escuridão densa do sangue e na prodigiosa elegância em que se movem demasiado lentos à beira do amor ou da perfeita solidão, à beira da despedida, um de cada vez, um após outro, perdendo-se, dançando-se.

[...] (GUSMÃO, 2004, p. 12, grifo do autor)

O poeta emprega caracteres em itálico para destacar o diálogo com uma sequência de In the Mood for Love, do chinês Wong Kar-Wai. Essa mancha gráfica diferente aliada às expressões que nos remetem ao filme e ao ritmo sugerido pelo cineasta - "corredores em ruínas", "caminho do desencontro", "música sem voz", "dança na escuridão", "demasiados lentos" - corroboram a apropriação do recurso cinematográfico no discurso poético de Gusmão. O autor apresenta a movimentação dos personagens ao subir e descer as escadas. Estas são sugestivamente musicais, uma vez que, a cada passo, impulsionam a sonoridade numa percussão que "chega alta e devagar" para que "se acenda ondulante e se interrompa breve" (GUSMÃO, 2004, p. 12). Aliás, o uso de aliterações, sobretudo com as consoantes nasais $/ \mathrm{m} /$ e $/ \mathrm{n} /$, e o prolongamento rítmico das mesmas reiteram a "prodigiosa elegância em que se movem demasiado lentos". A estratégia utilizada no texto é semelhante à lentidão das cenas, ao deslocamento do Sr. Chow e da Sra. Chan em slow-motion, já que as imagens verbalmente construídas parecem absorver o caráter vagaroso desses corpos músicos que dançam pelos degraus.

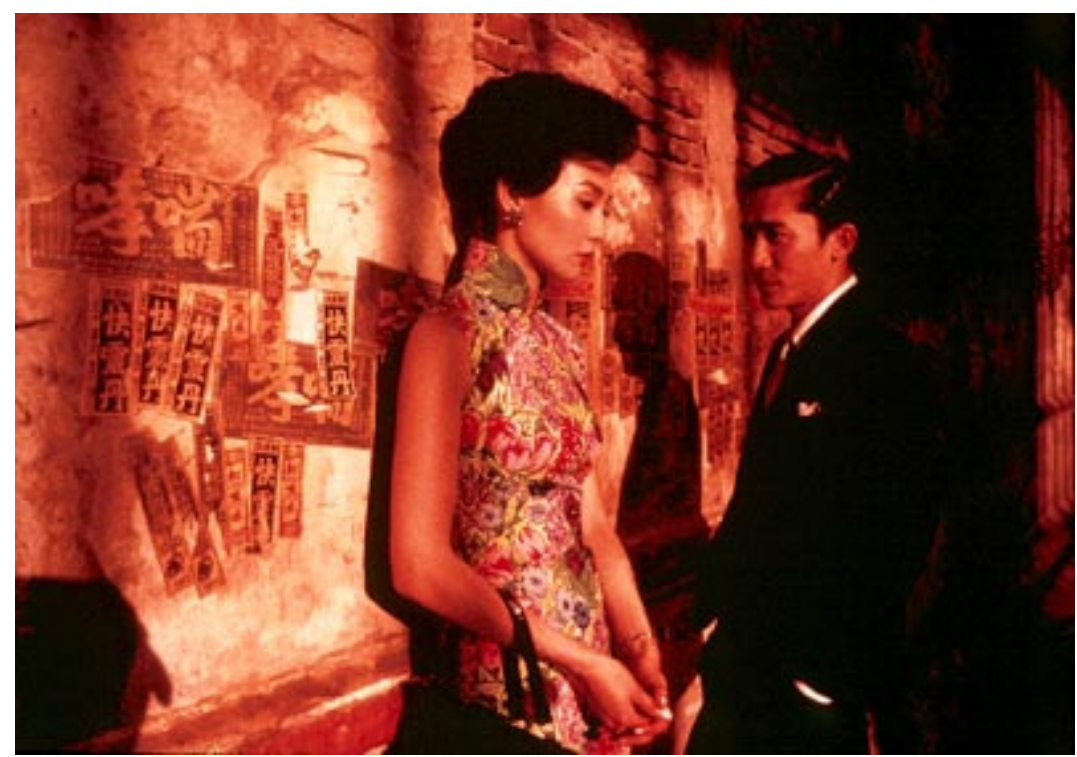

Figura 1: Cena do filme In the Mood for Love (2000) 
Vale ressaltar que Manuel Gusmão estabelece diálogo com Wong Kar-Wai, cineasta que investe na sugestão e na poeticidade das imagens de seus filmes. Tal investimento pode ser notado na exploração de recursos visuais como iluminação, cores fortes, enquadramentos, névoas, descontinuidades e mudanças de velocidade na diegese. Esses aspectos são captados pelo poeta na construção do texto. Há recorrentes fragmentos de "Como coisas caindo" que transmitem ao leitor-espectador essa atmosfera fílmica, entre eles destacamos as referências às luzes - "chegam cadentes/ alguns reflexos a laser", "as labaredas alucinam", "uma flauta se acenda ondulante", "escuridão densa do sangue" -; aos enquadramentos - "corredores em ruínas de uma metrópole/ falsa", "um de cada vez, um após outro, perdendo-se, dançando-se" -; aos movimentos do casal Sr. Chow e Sra. Chan - "apenas dois que tendo-se encontrado se procuram,/ que se afastam e se aproximam", "caminho/ do desencontro que é sua destinação sem destino", "movem-se demasiados lentos/ à beira do amor ou à da perfeita solidão". O jogo de enjambements assinalam as movimentações contínuas e descontínuas das cenas-versos de um "amor sem memória que não a da promessa".

Além de Wong Kar-Wai, Manuel Gusmão resgata de seu inventário imagético o filme Rosetta, dos irmãos belgas Luc e Jean-Pierre Dardenne, premiado com Palma de Ouro no Festival de Cinema de Cannes. Intitulando o poema "Imagens congeladas", o poeta procura, inicialmente, construir a visualidade textual com a focalização fixa que os cineastas empregaram ao filmar, com a câmera na mão, e ressaltar o ritmo asfixiante que é a vida da personagem.

Entra na sala escura e sua entrada projecta de novo a voz daquela jovem que se volta para a parede pobre e diz: Eu tenho um trabalho. Eu tenho um amigo. Eu estou a adormecer numa cama da casa do meu amigo. Eu sou normal. - Nas traseiras do império ela é normal. (GUSMÃO, 2004, p. 17, grifo do autor)

O ambiente de pobreza, a crítica sócio-política e a operária em busca de emprego são questões que os irmãos Dardenne conseguiram apresentar, relacionando objetividade fílmica com a subjetividade do olhar em torno de Rosetta. A expressividade e o turbilhão de sentimentos da jovem são captados a todo instante, ultrapassam a tela e chegam ao espectador na sala de cinema.

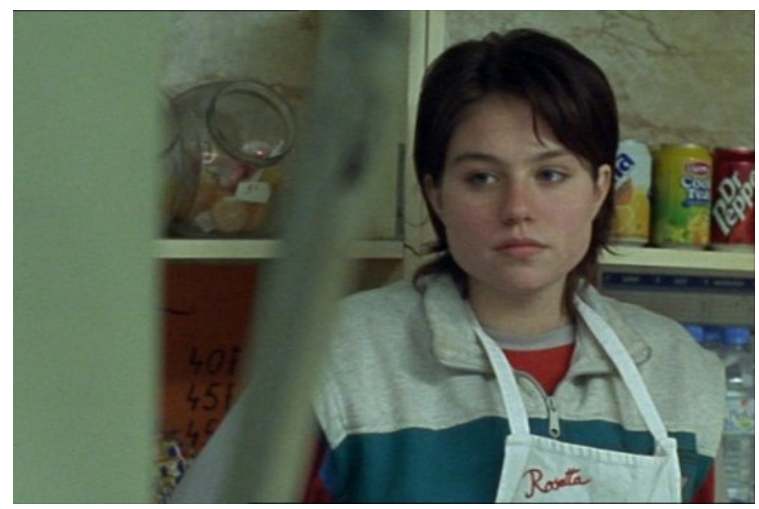

Figura 2: Cena do filme Rosetta (1999) 
Manuel Gusmão, mais uma vez, convida-nos a entrar na sala escura e a captar a projeção, que não se limita apenas ao écran, mas se expande nas letras do poema e expõe a memória de sons e de imagens, como por exemplo, a da voz de Rosetta a dizer: "Eu tenho um trabalho. Eu tenho um amigo. Eu/ estou a adormecer numa cama da casa do meu amigo./ Eu sou normal. A fala da jovem articulada entre os transitórios verbos ter e estar, apenas confirma com o verbo ser a normalidade de habitar uma "parede pobre" e a banalidade dessa condição no império capitalista. Realmente, a imagem se congela em Rosetta e o poeta traz à tona sua aposta numa antropogênese, tecendo a figuração e a refiguração do sujeito, o que confirma nossa hipótese de que há uma auratização do humano na poesia do referido autor. Nesse sentido, ele defende a escrita de uma promessa, embora incerta e sem força messiânica, e o desenvolvimento de um projeto ético e estético que revitalize a linguagem, o sujeito e o mundo: "Recapitulas o mundo/ Pelas imagens por onde respiras ainda.” (GUSMÃO, 2001, p. 39).

A opção dos irmãos Dardenne pelos close-ups na personagem e pela câmera turbilhonante é reiterada por Gusmão, visto que ele é poeta do movimento e sua relação com o cinema passa pelas regras da metamorfose. Desse modo, com sua caneta-câmera, quebra a fixidez da imagem e insere a técnica de montagem na sintaxe do poema, a fim de agenciar a sucessão de planos fixos e mobilizar as cenas-versos. Para isso, o poeta projeta no seu écran textual outra linguagem - a pictórica.

Mas alguém tem de continuar. Alguém caminha pelo corredor da morte: amorosa, apaixonadamente despede-se da infinita doçura do seu crime. E é esse amor sem perdão que o traz de volta ao teatro de sombras. No lume de gume imagina uma jovem levemente oblíqua: uma flor para o seu mal. Flectida a perna direita, a outra vem sobre ela junto ao tornozelo. Está assim numa pintura, sentada e vagamente olhando O lugar em que o pintor já não está; a não ser como um cão.

As sombras estremecem e mudam: É uma outra parede do labirinto: São várias pinturas guardando o silêncio. De cada vez, a mesma ou uma outra jovem está assim: Tem vestida uma camisa masculina que a despe de frente e abre o invisivel para o espelho e o pintor.

Uma delas, repetida oblíqua, ergue a perna esquerda, as mãos prendendo o joelho; esse pé em arco na beira da cadeira o outro poisa sobre chão: um mar varrido e encerrado. [...] (GUSMÃO, 2004, p. 18, grifo do autor)

Junto à cena de Rosetta, Gusmão faz montagens no seu poema-filme com os quadros criados por Balthus - pintor francês. É na escuridão cinematográfica, semelhante ao "corredor da morte" e "ao teatro das som- 
bras", que o poeta une imagens de jovens pertencentes a artes distintas e aparentemente desconexas. No entanto, os excertos "Mas alguém tem de continuar", "E é esse amor sem perdão que o traz de volta ao teatro de sombras" e "As sombras estremecem e mudam. É outra parede do labirinto." realizam um raccord entre as duas linguagens artísticas, garantindo a coerência fílmica e narrativa do poema.

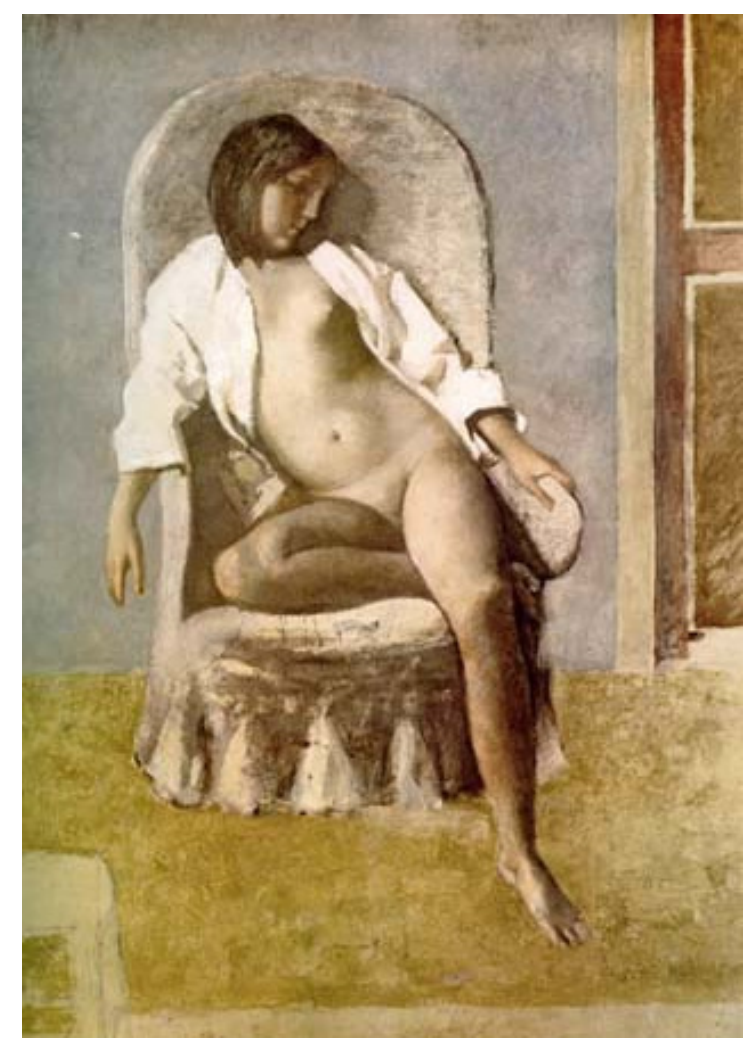

Figura 3: BALTHUS. Nu a descansar. 1957.

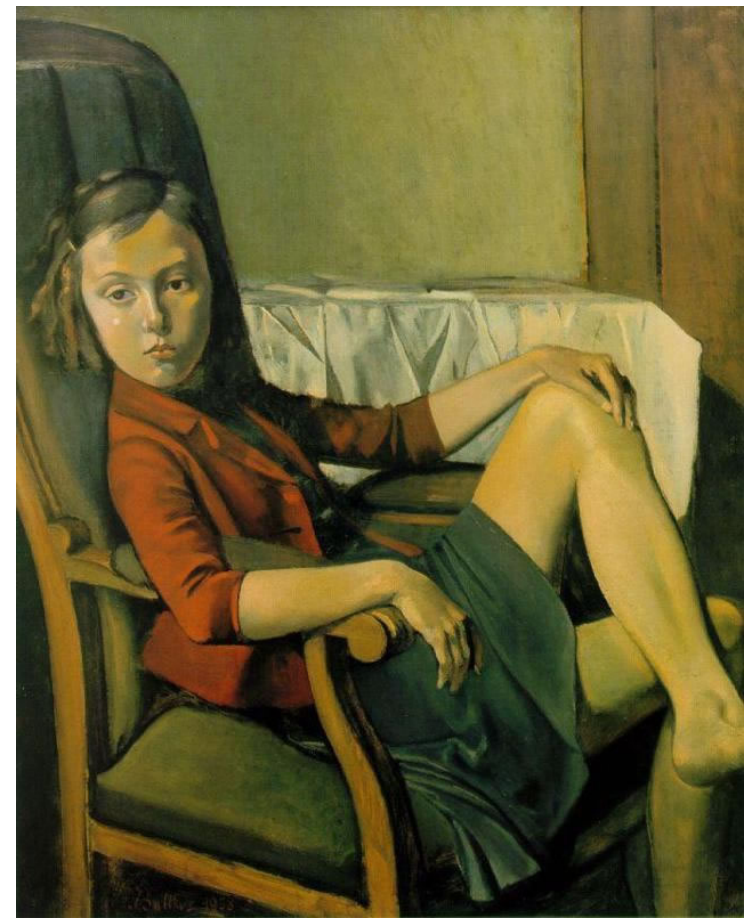

Figura 3: BALTUS. Sem título. 1948. 
Após a visualização dos quadros, poderíamos dizer que os versos de Manuel Gusmão propõem, numa primeira instância, um procedimento ecfrástico, já que são encontrados elementos descritivos no poema que fazem menção aos referidos trabalhos pictóricos - "uma jovem levemente oblíqua: uma flor para o seu mal.", "Tem vestida uma camisa masculina que a despe de frente", "Uma delas, repetida oblíqua, ergue a perna esquerda, as mãos/ prendendo o joelho; esse pé em arco na beira da cadeira/ o outro poisa sobre o chão" (GUSMÃO, 2004, p. 18). Contudo, os versos "No lume de gume imagina", "O lugar em que o pintor já não está" e "abre o invisível para o espelho e o pintor" apontam para uma cisão na proposta de ecfrasis, através da presença alucinatória e reflexiva de uma voz off que expressa a (im)possibilidade de clarificar o visível na linguagem poética, já que é traçado o jogo do velar e do desvelar inerente à palavra. Assim, o poeta escreve as lacunas entre ver e dizer o objeto estético ao atualizar o olhar e produzir nova imagem. De acordo com o que Gusmão poetiza: "São várias pinturas guardando o silêncio." (GUSMÃO, 2004, p. 18). Esse silêncio permite ao autor perceber os ecos de outras artes e organizar suas sequências fílmicas no cinema imaginário onde "as sombras estremecem e mudam" (GUSMÃO, 2004, p. 18).

Como podemos observar, as relações entre poesia e outras manifestações artísticas, sobretudo a dinamicidade cinematográfica, encontram um lugar relevante na poética de Manuel Gusmão. Por esse motivo, ele solicita um leitor-espectador participativo que se mova e se (co)mova com o corpo verbo-visual do poema.

O leitor voa letra a letra, do tempo para o tempo. "Voa outro", citando falsamente aquilo que lê: [...]

[...] - percebe o leitor que tudo se mistura e é de vários lados que fala, que soam os disparos. Porque sempre móvel o hipotético ponto de coincidência. E contudo é como se o ruído do motor, a velocidade da deslocação do corpo em movimento, a velocidade da luz e a metamorfose descontínua do território sobrevoado, se tornassem de uma nitidez evidente,

Como a do número finito das gotas de um rio que em flashes

sobrepostos se

despenhasse (GUSMÃO, 1990, p. 39)

Esse leitor-espectador, aceso e movido "pela chama de cada sílaba" que lê (GUSMÃO, 2001, p. 39), é convocado pelo poeta a adentrar a sala escura de seu cinema mental, em que as imagens se constroem através de planos variados, pontos de vista, montagens, raccords, movimentos e iluminações. A poesia fílmica de Manuel Gusmão torna-se um importante dispositivo do imaginário a possibilitar o diálogo entre as artes poéticas, pictóricas e cinematográficas e, além disso, faz-se um veículo de integração do humano com a incessante migração da linguagem. Desse modo, com seu cinepoiesis, o poeta nos propõe a árdua tarefa de transformação do “mundo em nós e fora de nós" (GUSMÃO, 2007, p. 2). 


\section{REFERÊNCIAS BIBLIOGRÁFICAS}

SILVA, Vítor Manuel de Aguiar e. Teoria e metodologias literárias. Lisboa: Universidade Menta, 1990.

AUMONT, Jacques. A imagem. 8 ed. São Paulo: Papirus, 1993. Naify, 2004. . O olho interminável [cinema e pintura]. São Paulo: Cosac \&

BELO, Ruy. Todos os poemas. Lisboa: Assírio \& Alvim, 2000.

CAMÕES, Luís de. Líricas. 10 ed. Lisboa: Sá da Costa, 1981.

CARO, Tito Lucrécio. A natureza das coisas. Lisboa: Typ. de Jorge Ferreira de Mattos, 1851.

DELEUZE, Gilles. A imagem-movimento: Cinema I. Lisboa: Assírio \& Alvim, 1983.

DIDI-HUBERMAN, Georges. O que vemos, o que nos olha. São Paulo: Editora 34, 1998.

FELLINI, Federico. Fazer um filme. Rio de Janeiro: Civilização Brasileira, 2000.

FREITAS, Manuel de. Uma Espécie de Crime: Apresentação do Rosto de Herberto Helder. Lisboa: \& Etc., 2001.

GONÇALVES, Aguinaldo José. Laokoon revisitado. São Paulo: EDUSP, 1994.

GUSMÃO, Manuel. “Da poesia como razão apaixonada. 3”. In: Poesia da Ciência, Ciência da Poesia III - Seminário da Faculdade de Letras de Coimbra. Coimbra: Faculdade de Letras e Fundação Calouste Gulbenkian, 1994. Caminho, 1990.

Dois Sóis A Rosa/ a arquitectura do mundo. Lisboa: Editorial

$$
\text { . "Entrevista conduzida por António Guerreiro". In: }
$$

BASÍLIO, Kelly Benoudis. Poesia e Arte. A Arte da Poesia. Lisboa: Editorial Caminho, 2008.

. "O inventor de imagens - Entrevista conduzida por Ricardo Paulouro". In: Textos e Pretextos. Lisboa, n.10, pp.24-33, outono/ inverno 2007. . Mapas/ o Assombro a Sombra. Lisboa: Editorial Caminho, 1996. . Migrações do fogo. Lisboa: Editorial Caminho, 2004. . Teatros do Tempo. Lisboa: Editorial Caminho, 2001.

HELDER, Herberto. Cinemas. In: Relâmpago. Lisboa, n. 3, pp.7-8, outubro de 1998.

. Photomaton \& Vox. Lisboa: Assírio \& Alvim, 2006. 
HOUAISS, Antonio. Dicionário da Língua Portuguesa. Rio de Janeiro: Objetiva, 2008.

JORGE, Luiza Neto. 19 Recantos e Outros Poemas. Org. Jorge Fernandes da Silveira e Maurício Matos. Rio de Janeiro, 7 Letras, 2008.

LOPES, Adília. Dobra - poesia reunida (1983-2007). Lisboa: Assírio \& Alvim, 2009.

MACIEL, Maria Esther. A memória das coisas: ensaios de literatura, cinema e artes plásticas. Rio de Janeiro: Lamparina, 2004.

MAGAlHÃES, Joaquim Manuel. Rima Pobre. Lisboa: Editorial Presença, 1999.

MARNER, Terence. A realização cinematográfica. Lisboa: Edições 70, 2006.

MARTELO, Rosa Maria. "Poesia, imagem e cinema: 'Qualquer poema é um filme'?". In: Revista do Instituto de Literatura Comparada Margarida Losa. V. 17. Porto: Faculdade de Letras da Universidade do Porto, 2007.

. Quando a poesia vai ao cinema. In: Relâmpago. Lisboa. n. 23, pp. 179-195, outubro de 2008.

MERLEAU-PONTY, Maurice. O olho e o espírito. São Paulo: Grifo Edições, 1969.

MESQUITA, Rosa Maria B. da C. Leite de. O Cinema do Tempo em Migrações do Fogo, de Manuel Gusmão. Dissertação de Mestrado. Porto: Faculdade de Letras da Universidade do Porto, 2007. 161p.

MIRANDA, Sá de. Sá de Miranda - Poesias. Lisboa: Gráfica Lisbonense, 1939.

PAZ, Octavio. O arco e a lira. Rio de Janeiro: Nova Fronteira, 1982.

. Signos em rotação. 3 ed. São Paulo: Perspectiva, 1996.

PESSANHA, Camilo. Clepsidra e poemas dispersos. 2 ed. Lisboa: Europa-América, 1999.

PESSOA, Fernando. Livro do Desassossego. São Paulo: Companhia das Letras, 2006.

VERDE, Cesário. Poesia completa (1855-1886). Lisboa: Dom Quixote, 2001.

\section{FILMOGRAFIA}

DARDENNE, Jean-Pierre e DARDENNE, Luc. Rosetta. [Filme - vídeo]. Produção e direção de Jean-Pierre Dardenne e Luc Dardenne. Bélgica/ França: USA Films, 1999. DVD/ NTSC, 95 min. color. son. Legendado: Esp. 
WONG, Kar-Wai. In the Mood for Love. [Filme - vídeo]. Produção e direção de Wong Kar-Wai. China: Paradis Filmes, 2000. DVD/ NTSC, 90 min. color. son. Legendado: Port.

Recebido para publicação em 22/02/12.

Aprovado em 15/04/2012.

\section{NOTAS}

1 Percebe-se que a relação entre ideia e imagem já existia entre os gregos, uma vez que esta era compreendida como uma projeção da mente, algo que se inseria num processo de representação.

2 Chamamos de simulação técnica as formas de produção imagética empregadas pelas novas tecnologias, assim como sua capacidade de alterar a realidade, interferindo em dimensões, luminosidade e aspectos dos objetos visualizados.

3 Para Manuel Gusmão, a poesia é arte concebida como “razão apaixonada”, em que técnica e expressão, conhecimento e sensibilidade constituem elementos fulcrais para sua composição. Ela é "razão que não perde pelo caminho o sensível” (GUSMÃO, 1994, p. 234). Tal ideia faz da poesia um "discurso-razão" (GUSMÃO, 1994, p. 234) que não está restrita à racionalidade, mas também não se volta para um extremo campo sensitivo.

4 A relação que Manuel Gusmão estabelece entre o clinamen e a escrita poética apresenta ecos perceptíveis das palavras de Lucrécio, conforme se percebe no seguinte trecho de $A$ natureza das coisas: "Se da ordem por que as lettras se introduzem;/ Tal do universo aos atomos succede:/ Muda-lhes as distancias, as figuras,/ A direcção, o choque, o peso, o nexo,/ Ordem, collocação, concursos, motos,/ Veras que os corpos igualmente mudam." (CARO, 1851, p. 125).

5 Cita-se aqui um fragmento do Canto II de A natureza das coisas, de Tito Lucrécio Caro, mantendo a grafia original da tradução feita por António José de Lima Leitão, em 1851: "Como as gotas cahir vimos da chuva:/ Nos atomos assim nunca se dera/ Encontro ou choque, e à natureza nunca/ Producções engendrar seria dado./ Suppondo-se que os corpos de mais peso/ Em linha recta pelo vacuo cahem/ Mais apressados que os que são mais leves;/ E que d'est'arte se realizam choques/ Que movimentos productores causam;/ É afastar-se de rasão mui longe./ [...] Na acção da queda, os corpos vão rompendo,/ Mais se aceleram quanto são mais graves:/ Nunca os mais graves poderão de cima/ Cahir sobre os mais leves, sendo a causa/ De choques que as acções criam diversas/ Pelas quaes gera a natureza as coisas." (CARO, 1851, p. 89-91).

6 É interessante ressaltar que a ideia de verticalidade e de queda de que fala Herberto Helder é algo recorrente na tradição lírica portuguesa, como se pode verificar nos versos de Camões - "Aqui estive eu co'estes pensamentos/ gastando o tempo e a vida; os quais tão alto/ me subiam nas asas, que caía (e vede se seria leve o salto!)/ de sonhados e vãos contentamentos" (CAMÕES, 1981, p. 68) - ; de Sá de Miranda - "O sol é grande, caem co’a calma as aves/ do tempo em tal sazão, que soe ser fria;/ esta água que do alto cai, acordarm'ia/ do sono não, mas de cuidados graves." (MIRANDA, 1939, p. 29) -; de Camilo Pessanha - "Meus olhos apagados/ Vede a água cair./ Das beiras dos telhados,/ Cair, sempre cair.// Das beiras dos telhados,/ Cair, quase morrer.../ Meus olhos apagados,/ E cansados de ver." (PESSANHA, 1999, p. 118); de Cesário Verde - "Por baixo, que portões! Que arruamentos!/ Um parafuso cai nas lajes, às escuras” (VERDE, 2001, p. 130) -; de Fernando Pessoa - "Oiço cair o tempo, gota a gota, e nenhuma gota que cai se ouve cair." (PESSOA, 2006, p. 64); assim como versos de poetas contemporâneos, entre os quais se encontram os de Luíza Neto Jorge - "O poema ensina a cair/ sobre vários solos/ [...] até à queda vinda/ da lenta volúpia de cair" (JORGE, 2008, p. 64); os de Adília Lopes - "Cair do cavalo/ cair da escada/ cair em mim" (LOPES, 2009, p. 348) -; os de Manuel de Freitas - "[...] um cigarro/ que caindo dos dedos se esmaga no chão." (FREITAS, 2001, p.13) - , entre outros nomes relevantes. 